$$
\text { DOE } / f^{\mathrm{DE} / \mathrm{DC} / 89760--\mathrm{T} 6} 004867
$$

\title{
A NOVEL APPROACH TO HIGHLY DISPERSING CATALYTIC MATERIALS IN COAL FOR GASIFICATION
}

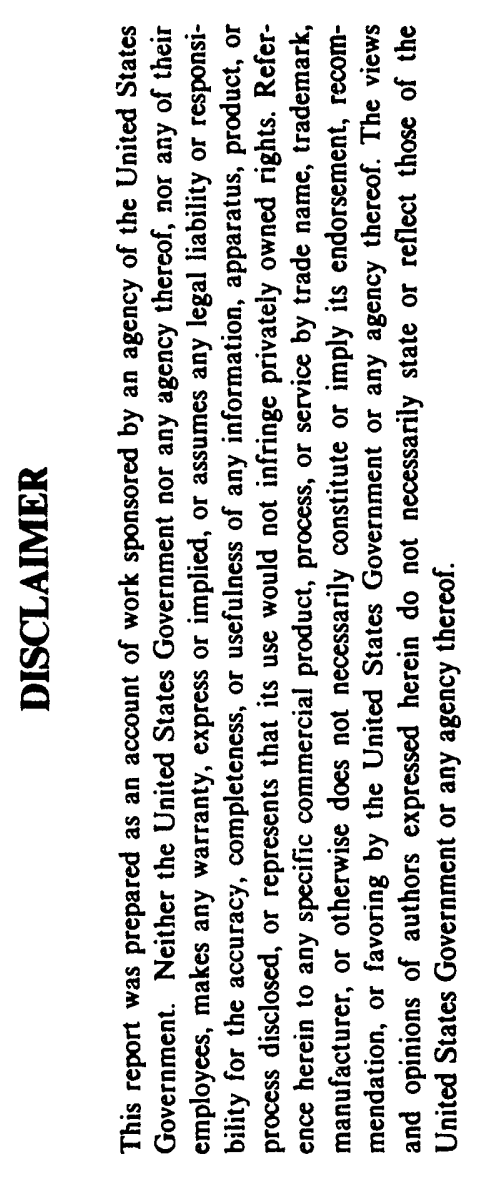

\author{
Eight Quarterly Report \\ for the Period \\ July 1, 1991 - September 30, 1991 \\ Godfried M.K. Abotsi and Kofi B. Bota \\ Principal Investigators
}

Research Center for Science and Technology

Clark Atlanta University

Atlanta, GA 30314

\author{
PREPARED FOR \\ UNITED STATES DEPARTMENT OF ENERGY \\ UNDER CONTRACT NO. DE-FG22-89PC89760
}

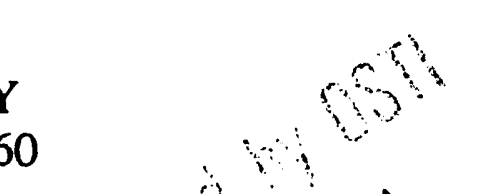




\section{DISTRIBUTION}

Dr. Jagdish L. Malhptra

U.S. Department of Energy

Morgantown Energy Technology Center

P.O. Box 880

Morgantown, WV

Marilyn Keane

PM-40, MS922-206

U.S. Department of Energy

Pittsburgh Energy Technology Canter

P.O. Box 10940

Pittsburgh, PA 15236

Cynthia Y. Mitchell

Contract Specialist

AD-22, 921-165

U.S. Department of Energy

Pittsburgh Energy Technology Center

P.O. Box 10940

Pittsburgh, PA 15236

Kay Downey

Office of Technology Transfer

U.S. Department of Energy

Mail Stop 58-M217

Pittsburgh Energy Technology Center P.O. Box 10940

Pittsburgh, PA 15236

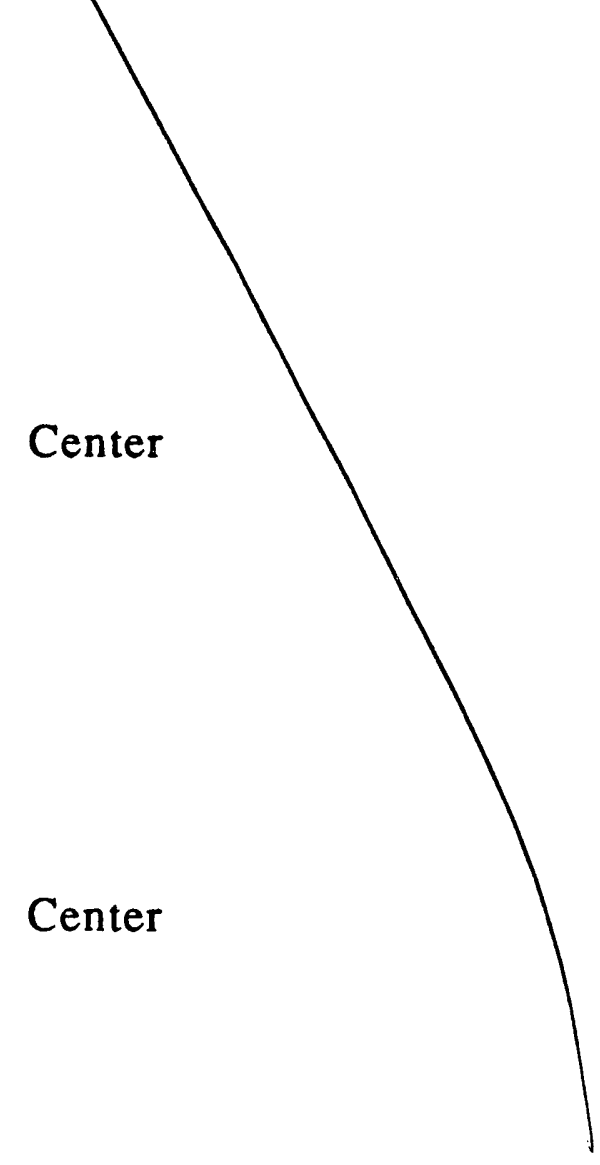




\section{ABSTRACT}

This project seeks to develop a technique, based on coal surface properties, for highly dispersing catalysts in coal for gasification and to investigate the potential of using potassium carbonate and calcium acetate mixtures as catalyst for coal gasification. The lower cost and high catalytic activity of the latter compound will produce economic benefits by reducing the amount of $\mathrm{K}_{2} \mathrm{CO}_{3}$ required for high coal char reactivities.

The effects of potassium impregnation conditions ( $\mathrm{pH}$ and coal surface charge) on the reactivities, in carbon dioxide, of chars derived from demineralized lignite, subbituminous and bituminous coals have been determined. Impregnation of the acid-leached coal with potassium from strongly acidic solutions resulted in initial slow char reactivity which progressively increased with reaction time. Higher reactivities were obtained for catalyst (potassium) loaded at pH 6 or 10. The dependence of char gasification rates on catalyst addition pH increased in the order: $\mathrm{pH} 6 \sim \mathrm{pH} 10>>\mathrm{pH}$ 1. 


\section{INTRODUCTION}

Catalyzed coal gasification requires the adsorption of the catalyst precursor onto the coal surface as the first step in a series of consecutive reactions. Previous studies (1) have shown that char reactivities are dependent on the catalyst precursor and the method applied to load the coal witn the catalyst. This report is part of ongoing research aimed at understanding the roles of coal surface charge and the $\mathrm{pHs}$ of catalyst impregnating solutions on the adsorption and activities of calcium acetate and potassium carbonate. As reported previously (2), the reactivities of chars derived from a lignite, subbituminous, and bituminous coals are strongly dependent upon the coal surface charge and the pHs at which calcium was adsorbed onto the coal. The current report discusses the reactivities of the demineralized coals in carbon dioxide, catalyzed by potassium.

\section{EXPERIMENTAL}

The chemical composition of the coals and the procedure for the particle electrokinetic measurements have been described earlier (2). The catalytic activities of the inherent inorganic materials were minimized by demineralization of the coals by treatment in $\mathrm{HF}$ and $\mathrm{HNO}_{3}$ solutions prior to use. Potassium was adsorbed at $\mathrm{pH} 1,6$ or 10 by mechanically agitating $50.0 \mathrm{~cm}^{3}$ of $5 \times 10^{-2}$ moles $\mathrm{I}^{-1}$ solutions of $\mathrm{K}^{+}$(using potassium carbonate) with $1.0 \mathrm{~g}$ samples of the coals for $24 \mathrm{~h}$. The $\mathrm{pHs}$ of the slurries were adjusted with nitric acid or ammionium hydroxide solutions. Potassium adsorption was determined by both chemical analysis (by Galbraith Laboratories) of the filtered solids and of the filtrates using atomic absorption spectrophotometry. 
The potassium-loaded coals were pyrolyzed by heating (at $20^{\circ} \mathrm{C} \mathrm{min-1)} \mathrm{to}$ $800^{\circ} \mathrm{C}$ in nitrogen $\left(100 \mathrm{~cm}^{3} \mathrm{~min}^{-1}\right)$ and holding at this temperature for $0.5 \mathrm{~h}$. The $\mathrm{N}_{2}$ supply was then switched off, $\mathrm{CO}_{2}$ was introduced at the same flow rate, and char reactivity was conducted at $800^{\circ} \mathrm{C}$ for about $2 \mathrm{~h}$.

\section{RESULTS AND DISCUSSION}

Table 1 shows that, in general, potassium adsorption onto the demineralized coals increased with increase in the pHs of the coal slurries. The deviations from the $\mathrm{pH}$ values were $\pm \mathrm{pH} 0.2, \pm \mathrm{pH} 0.5, \pm \mathrm{pH} 0.2$ for potassium adsorption at $\mathrm{pH} 1, \mathrm{pH} 6$ and $\mathrm{pH} 10$, respectively. It can be seen that the differences in the potassium content of the coals is less pronounced at $\mathrm{pH} 6$ or 10 . The similar potassium adsorption values at these pHs implies that coulombic attraction of the potassium ion onto the coal surface is not significantly increased by raising the coal slurny $\mathrm{pH}$, and hence the net negative surface charge densities, of the coals. As reported previously (3), unlike potassium, calcium uptake approximately doubled by increasing the pHs of the coal dispersions from $\mathrm{pH} 6$ to 10 . The increased calcium loading is attributed to the divalent nature of the calcium ion $\left(\mathrm{Ca}^{2+}\right)$ which promotes electrostatic attraction between $\mathrm{Ca}^{2+}$ and the anionic coal surface in accordance with the Schulze- Hardy rule (4) which states that the extent of adsorption of an ionic species is directly related to the magnitude of the ionic charge on the adsorbate. The adsorption trends correlate the zeta potentials of the coal particles which become more negatively charged with increase in the $\mathrm{pHs}$ of the coal dispersions. The zeta potentials ranged from about -10 $\mathrm{mV}$ at $\mathrm{pH} 1$ to about $-110 \mathrm{mV}$ at $\mathrm{pH} 10$ (3). This indicates that electrostatic attraction between the potassium ions $\left(\mathrm{K}^{+}\right)$and the negatively charged surface is the dominant driving force for adsorption. 
Table 1. Dependence of calclum adsorption on catalyst loading pH.

Potassium content, \% wt.

Demineralized Coal

Lignite

Subbituminous

Bituminous

Metal

pH 1 pH 6 pH 10

K

0.4

2.0

2.1

$\mathrm{K}$

0.2

1.9

2.6

K

0.2

3.5

2.3

The amounts of carbon burn-off as a function of reaction time for the demineralized potassium-loaded chars are shown in Figures 1-3 for the lignite, subbituminous and bituminous coals, respectively. The calcium catalyzed gasification activities have been reported previously (5). A striking difference between Figures 1, 2 and 3 is that potassium addition to the lignite at $\mathrm{pH} 1$ produced a prominently higher gasification rates than potassium introduction into the subbituminous and the bituminous coals at the same $\mathrm{pH}$. In fact, above $95 \mathrm{~min}$. of reaction, the $\mathrm{pH} 1$ char became more reactive than both the $\mathrm{pH} 6$ or 10 samples. Repeated experiments with different samples of the coal loaded with potassium at $\mathrm{pH} 1$ gave similar results. Thus, this finding can not be attributed to experimental artifacts. Reasons for this peculiar behavior are not clear, but it is possible that for this coal, very high initial potassium dispersion occurred at $0.4 \% \mathrm{wt} . \mathrm{K}$ and that this level of dispersion was maintained as the reaction progressed. In contrast, it appears that the dispersion of the potassium catalysts loaded at $\mathrm{pH} 6$ or 10 decreased with reaction time as evidenced by the constant reactivities after about 25-50 min. on stream.

The reactivities of the demineralized chars in the presence of calcium and potassium are compared in Table 1. Reactivities were obtained using the equation (6): 


$$
R=d g
$$

where $\omega$ is the initial weight of char (dry, ash-free) and $d w / d t$ is the rate of char gasification at $1.5 \mathrm{~h}$.

\section{Table 1}

Reactivities of the Calcium- or Potassium- Exchanged Coals as a Function of Catalyst Loading pH and Metal Content

\begin{tabular}{lrccc}
\hline $\begin{array}{l}\text { Demineralized } \\
\text { Coal }\end{array}$ & $\mathrm{pH}$ & $\begin{array}{c}\text { Metal adsorbed, \% wt. } \\
\mathrm{Ca}\end{array}$ & $\mathrm{K}$ & $\begin{array}{c}\text { Reactivity } \\
\mathrm{h}^{-1}\end{array}$ \\
\hline Lignite & 1 & 0.3 & & 0.28 \\
& 6 & 4.3 & & 0.44 \\
& 10 & 7.2 & 0.4 & 0.33 \\
& 1 & & 2.0 & 0.44 \\
Subbituminous & 6 & & 2.1 & 0.52 \\
& 10 & & & 0.16 \\
& 1 & 0.2 & & 0.31 \\
& 6 & 2.9 & & 0.25 \\
& 10 & 7.8 & 0.2 & 0.18 \\
& 1 & & 1.9 & 0.72 \\
Bituminous & 6 & & 2.6 & 0.60 \\
& 10 & & & 0.06 \\
& 1 & 0.1 & & 0.23 \\
& 6 & 3.3 & & 0.25 \\
& 10 & 5.9 & 0.2 & 0.17 \\
& 1 & & 3.5 & 0.47 \\
& 6 & & 2.3 & 0.30 \\
\hline
\end{tabular}

Figures 1-3 and Table 1 show that potassium is a more effective gasification catalyst than calcium, the maximum char reactivities being $0.72 h^{-1}$ and $0.44 h^{-1}$ for potassium and calcium, respectively. For all the coals, high calcium loadings $(5.9,7.2$ 
and $7.8 \% w$ w.) at $\mathrm{pH} 10$ produced lower gasification rates compared to the lower calcium additions $(2.9,3.3$ and $4.3 \% w t . \mathrm{Ca})$ at $\mathrm{pH} 6(5)$. The reduced activities could be due to pore plugging by the high amounts of calcium which inhibits access of $\mathrm{CO}_{2}$ to the pores of the chars and/or to reduced catalyst dispersion at the higher calcium loadings. Examination of the calcium-containing coals by $x$-ray diffraction using CuKa radiation gave diffraction peaks characteristic of $\mathrm{CaO}(7)$ for the samples loaded at $\mathrm{pH}$ 10 whereas no reflections above the background of the coals were obtained for catalyst addition at the lower $\mathrm{pH}$ values. The absence of diffaction peaks has been attributed to high calcium dispersion while their presence is indicative of reduced catalyst dispersion and the concomitant lower activity at pH 10.

Hippo et. al. $(6,8)$ have shown that the reactivities of Darco seam, Texas lignite chars in carbon dioxide and in steam at $650^{\circ} \mathrm{C}$ progressively increased with increase in the calcium content (which ranged from 1.1 to $12.9 \%$ wt. Ca) of the chars. Unlike the current work, calcium was exchanged onto chars which have been previously prepared in $\mathrm{N}_{2}$ at $800^{\circ} \mathrm{C}$. In addition, these investigators did not observe any dependence of char burn-off on calcium adsorption pH from their "limited results obtained" and there were no indications of the pHs of the coal slurries. However, Hengel and Walker (9) have shown that calcium loadings greater than $4 \%$ wt. resulted in no further increase in the $\mathrm{CO}_{2}$ reactivities at $755^{\circ} \mathrm{C}$ of chars derived from a demineralized Montana (Fort Union seam) lignite. Recently, similar findings have been reported for the $\mathrm{CO}_{2}$ gasification (at $775^{\circ} \mathrm{C}$ ) of polymer derived carbons onto which various levels of calcium $(0.5-9.5 \% \mathrm{wt} . \mathrm{Ca}$ ) have been ion-exchanged (10). Since similar $\mathrm{N}_{2}$ and $\mathrm{CO}_{2}$ surface areas were obtained for the carbons used in the latter study, the differences in reactivities can not be attributed to differences in the surface areas or the carbons. $\mathrm{CO}_{2}$ surface area measurements on samples of the demineralized bituminous coal loaded with calcium or potassium at $\mathrm{pH} 1,6$ or 10 gave 
similar values $\left(\sim 11-20 \mathrm{~m}^{2} \mathrm{~g}^{-1}\right)$, suggesting that the reactivities are independent of surface area.

\section{CONCLUSIONS}

The influence of measured coal surface charge on the adsorption of calcium or potassium from solution prior to gasification has been investigated. The study focused on the demineralized derivaties of three ranks of coal: a lignite, subbituminous and bituminous coals and their demineralized derivatives. To minimize the interference of the coals inherent inorganic materials with the added calcium or potassium, the metal adsorption and gasification studies were restricted to the demineralized (DEM) coals. Potassium was ion-exchanged onto the DEM samples at about pH 1, pH 6 and $\mathrm{pH} 10$. In strongly acidic environments ( $\mathrm{pH} 1)$, potassium uptake was very low $(0.2-0.4 \%$ $w t)$, suggesting minimal electrostatic attraction between the cations and the slightly negatively charged coal surface. However, potassium adsorption increased dramatically as the $\mathrm{pHs}$ of the slurries were raised to $\mathrm{pH} 6$ or 10 . Potassium uptake followed the order: $\mathrm{pH} 6 \sim \mathrm{pH} 10>\mathrm{pH} 1$, the average potassium concentration in the coals being $0.2 \%$ wt. $\mathrm{K}$ and $2.5 \% \mathrm{wt} . \mathrm{K}$ at $\mathrm{pH} 1$ and $\mathrm{pH} 6$, respectively.

The reactivities of the potassium-containing chars in $\mathrm{CO}_{2}$ at $800^{\circ} \mathrm{C}$ were also strongly dependent on the $\mathrm{pHs}$ at which the metals were exchanged onto the coals. Char reactivities in the presence of potassium followed the trend $\mathrm{pH} 6 \sim \mathrm{pH} 10>\mathrm{pH}$ 1 , consistent with the potassium contents. This work also shows that when ionexchanged at $\mathrm{pH} 6$ or 10 , potassium is a very active catalyst for the $\mathrm{CO}_{2}$ gasification of demineralized samples of a North Dakota lignite, Montana subbituminous and illinois No. 6 bituminous coals and that char reactivities are dependent on the $\mathrm{pH}$, and hence, on the magnitude of the negative surface charge densities on the coals during catalyst loading form solution. 
In the next quarter, the effects of co-adsorption of calcium and potassium and the surface areas of the coals on char reactivity will be evaluated.

\section{HIGHLIGHT ACCOMPLISHMENTS, ARTICLES AND PRESENTATIONS}

Publications and presentations resulting from this work to date are provided below.

1. Abotsi, G.M.K., Bota, K.B., Gautam Saha, "The Influence of Coal Surface Chemistry on the Adsorption of Coal Conversion Catalysts," Am. Chem. Soc., Div. Fuel Chem. Preprs. 1990, 35(3), 606-610.

2. Abotsi, G.M.K., Bota, K.B. and Gautam Saha, "Electrophoresis as an Aid to Improved Catalyst Dispersion in Coal, " 17 th Annual National Conference of the National Organization for the Professional Advancement of Black Chemists and Chemical Engineers, 1990, Abstracts, p. 77.

3. Abotsi, G.M.K., Bota, K.B., Saha, G., "Relationships Between Coal Surface Chemistry, Catalyst Adsorption, and Char Reactivity," American Carbon Society, 20th Biennial Conference on Carbon, Extended Abstracts, 460-461, 1991.

4. Abotsi, G.M.K., Bota, K.B., Saha, G., "Enhancement of Coal Gasification Activity by Coal-Catalyst Interactions," International Energy Agency, International Conference on Coal Science Proceedings, 412-415, 1991.

5. Abotsi, G.M.K., Bota, K.B., Saha, G., "Effects of Coal Surface Charge on the Adsorption and Gasification Activities of Calcium and Potassium," Submitted to Fuel Science \& Technology International.

The effects of measured coal surface charge on the adsorption of coal gasification metal catalysts has not been studied previously. This work has shown that the adsorption of calcium or potassium ions onto coals is primarily controlled by the surface charge properties of coal. Coal loading (by ion-exchange) of $\mathrm{Ca}^{2+}$ or $\mathrm{K}^{+}$at high pHs which promote the formation of negatively charged coal surface enhanced coulombic attraction between the metal ions and the coal surface with a resultant enhancement of char reactivity. However, char reactivity is reduced by catalyst 
addition from strongly acidic solution due to the minimal electrostatic attraction between the cations and the reduced net negative charge on the coal surface.

\section{REFERENCES}

1. Wood, B.J. and Sancier, K.M., 1984, Catal_Rev_-Sci.Eng., 26(2), 233-279.

2. Abotsi, G.M.K., Bota, K.B. and Saha, G.,1990, Am. Chem. Socu Div. Fuel Chem. Prepr 35(3), 606-610.

3. Abotsi, G. M. K. and Bota, K. B., 1990. "A Novel Approach to Highly Dispersing Catalytic Materials in Coal for Gasification," Fourth Quarterly Report prepared for the Department of Energy under contract no. DE-FG2289 PC89760.

4. Adamson, A.W., 1976. "Physical Chemistry of Surfaces," 3rd edn., John Wiley, New York, p. 325.

5. Painter, P.C. and Coleman, M.M., 1979, Euel 58, 301.

6. Hippo, E.J., Jenkins, R.G. and Walker, P.L., Jr., 1979. Enhancement of lignite char reactivity to steam by cation addition. Fuel, 58: 338-334.

7. Radovic, L.R., Walker, P.L., Jr. and Jenkins, R.G., 1983, Euel 62, 209-212.

8. Linares-Solano, A., Hippo, E.J. and Walker, P.L., Jr., 1986. Catalytic activity of calcium for lignite char gasification in various atmospheres. Fuel, 65: 776-779.

9. Hengel, T.D. and Walker, P.L., Jr., 1984. Catalysis of lignite char gasification by exchangeable calcium and magnesium. Fuel, 63: 12141221.

10. Martinez de Lecea, C.S., Almela-Alarcon and Linares-Solano, A., 1990. Calcium-catalyzed carbon gasification in $\mathrm{CO}_{2}$ and steam. Fuel, 69:21-27. 


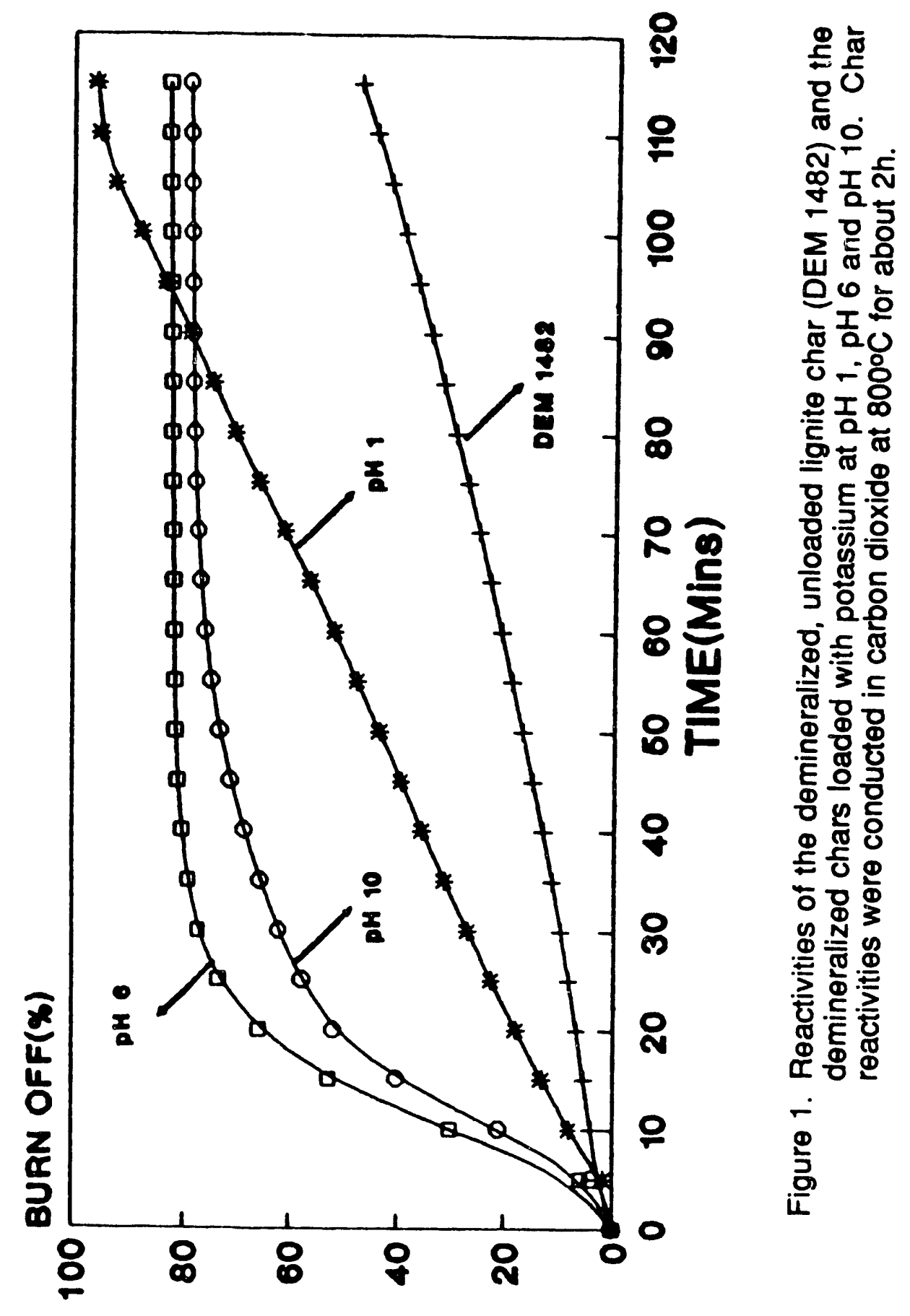




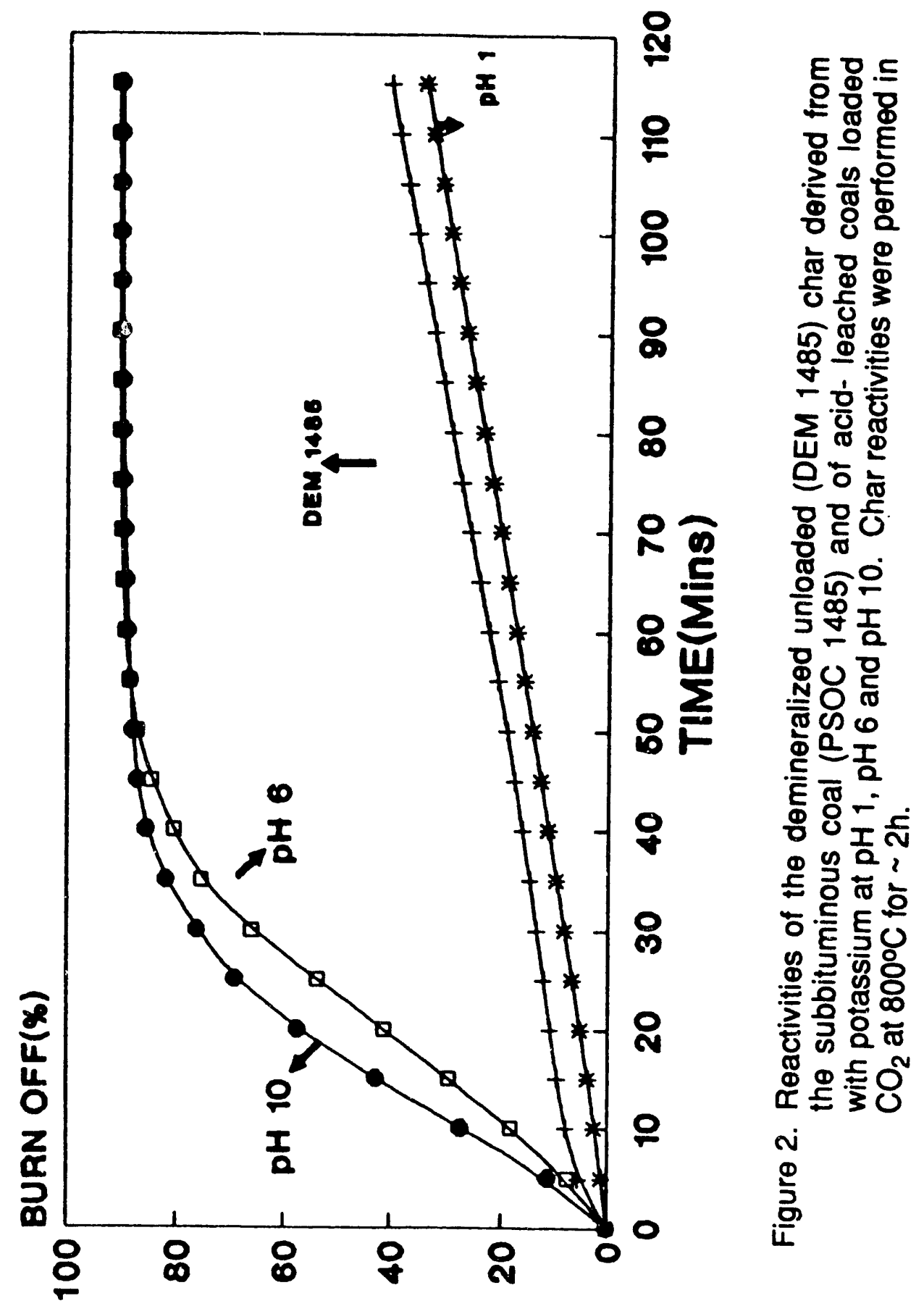




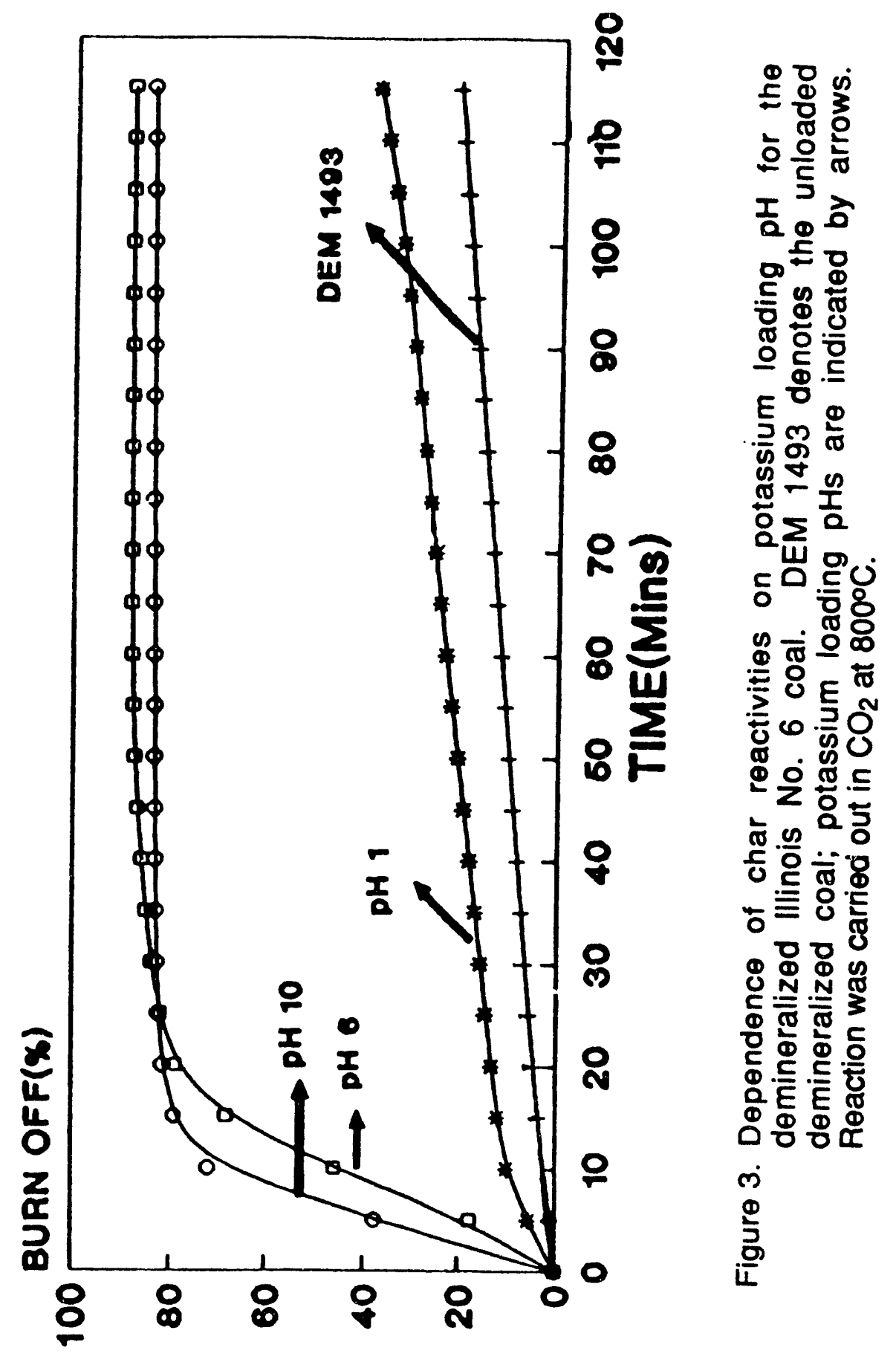



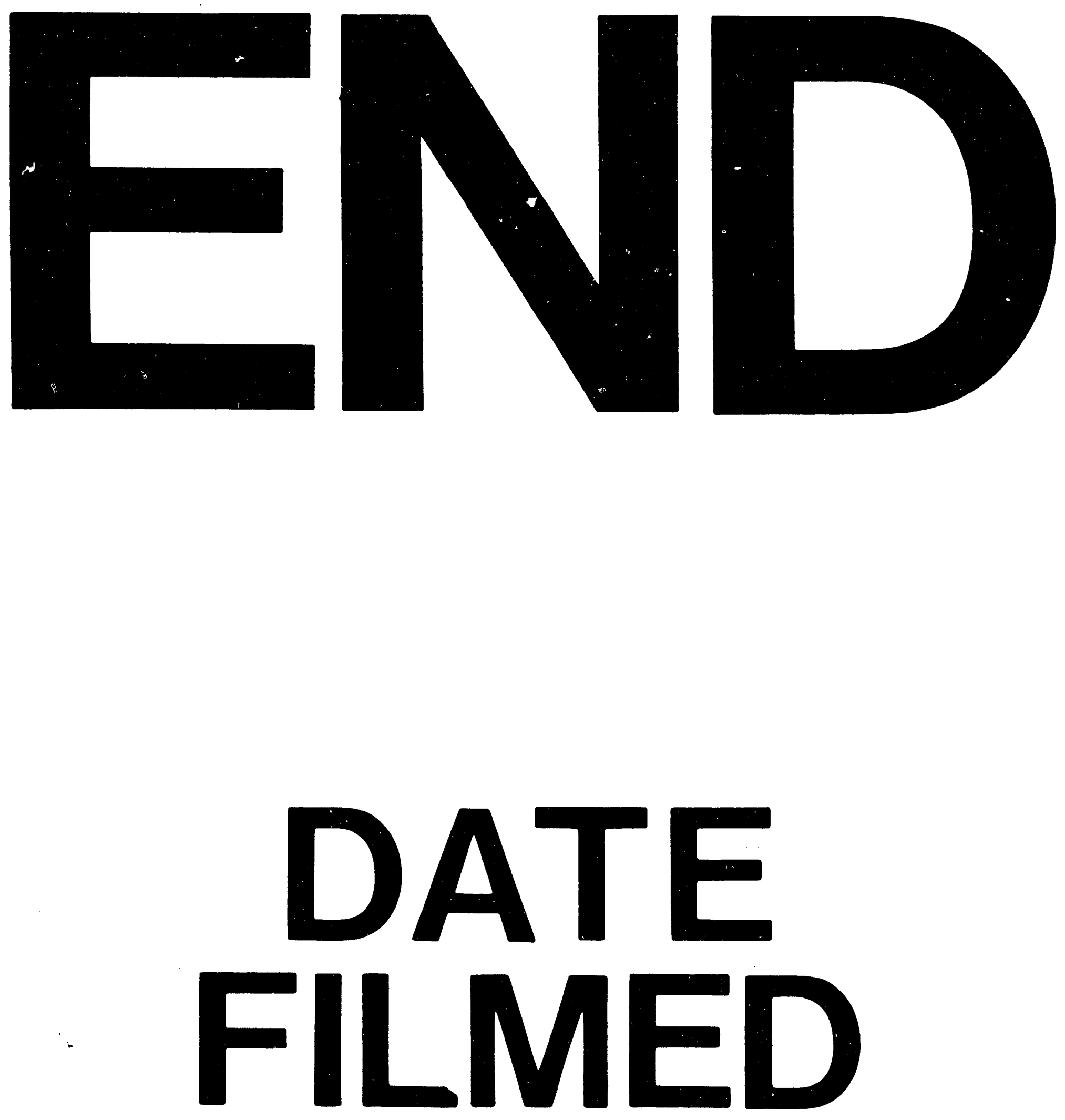

I

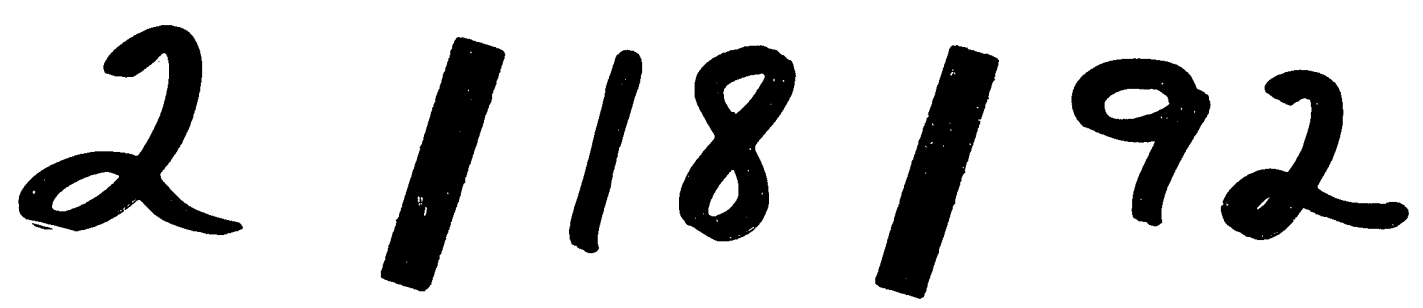


